\title{
Phelan-McDermid syndrome: a review of the literature and practice parameters for medical assessment and monitoring
}

Alexander Kolevzon 1,2,3,10,11*, Benjamin Angarita ${ }^{1,2}$, Lauren Bush ${ }^{1,2}$, A Ting Wang 1,2,4,10, Yitzchak Frank 1,2,3,5, Amy Yang ${ }^{6}$, Robert Rapaport ${ }^{3,7}$, Jeffrey Saland ${ }^{3}$, Shubhika Srivastava ${ }^{3,8}$, Cristina Farrell ${ }^{1,3,9}$, Lisa J Edelmann ${ }^{6}$ and Joseph D Buxbaum ${ }^{1,2,4,6,10,11}$

\begin{abstract}
Autism spectrum disorder (ASD) and intellectual disability (ID) can be caused by mutations in a large number of genes. One example is SHANK3 on the terminal end of chromosome 22q. Loss of one functional copy of SHANK3 results in 22q13 deletion syndrome or Phelan-McDermid syndrome (PMS) and causes a monogenic form of ASD and/or ID with a frequency of $0.5 \%$ to $2 \%$ of cases. SHANK3 is the critical gene in this syndrome, and its loss results in disruption of synaptic function. With chromosomal microarray analyses now a standard of care in the assessment of ASD and developmental delay, and with the emergence of whole exome and whole genome sequencing in this context, identification of PMS in routine clinical settings will increase significantly. However, PMS remains a rare disorder, and the majority of physicians have never seen a case. While there is agreement about core deficits of PMS, there have been no established parameters to guide evaluation and medical monitoring of the syndrome. Evaluations must include a thorough history and physical and dysmorphology examination. Neurological deficits, including the presence of seizures and structural brain abnormalities should be assessed as well as motor deficits. Endocrine, renal, cardiac, and gastrointestinal problems all require assessment and monitoring in addition to the risk of recurring infections, dental and vision problems, and lymphedema. Finally, all patients should have cognitive, behavioral, and ASD evaluations. The objective of this paper is to address this gap in the literature and establish recommendations to assess the medical, genetic, and neurological features of PMS.
\end{abstract}

Keywords: Phelan-McDermid syndrome, 22q13 deletion syndrome, SHANK3, Autism, Autism spectrum disorder, Neurodevelopmental disorders, Practice parameters

\section{Review Introduction}

Gene discovery approaches, followed by functional analysis of model systems, have elucidated the neurobiology of several genetic subtypes of autism spectrum disorder (ASD). ASD can now be conceived of as having many distinct genetic risk genes and one example is SHANK3 on terminal chromosome 22q. Studies indicate that loss of one functional copy (haploinsufficiency) of SHANK3

\footnotetext{
* Correspondence: alexander.kolevzon@mssm.edu

'Seaver Autism Center for Research and Treatment, Icahn School of Medicine at Mount Sinai, One Gustave L. Levy Place, New York, NY 10029, USA

${ }^{2}$ Department of Psychiatry, Icahn School of Medicine at Mount Sinai, One

Gustave L. Levy Place, New York, NY 10029, USA

Full list of author information is available at the end of the article
}

through deletion or mutation causes a monogenic form of ASD with a frequency of at least $0.5 \%$ of ASD cases [1-7]. The rate of SHANK3 loss in children with moderate to profound intellectual disability (ID) appears to be up to $2 \%[1,6]$. SHANK3 is the critical gene in this syndrome $[2,8]$, and its loss is sufficient to cause Phelan-McDermid syndrome (PMS; OMIM ID 606232). SHANK3 encodes a scaffolding protein in the postsynaptic density of glutamatergic synapses and is known to play a critical role in synaptic function [9]. Although SHANK3 deletions and mutations account for a relatively small proportion of ASD and ID cases, recent evidence suggests that many different genetic causes of ASD and ID converge on several common pathways, including the SHANK3 pathway $[10,11]$. Using Shank3-deficient mice, specific deficits in 
synaptic function and plasticity in glutamatergic signaling have been documented [12-17]. Interestingly, reversal of synaptic deficits has been shown with an experimental therapeutic (insulin-like growth factor-1; IGF-1) in mouse [18] and human neuronal models [19]. With chromosomal microarray now recommended as a standard of care for the assessment of ASD [20-23], it is expected that identification of PMS will increase significantly in routine clinical settings. To date, about 1,200 cases have been identified worldwide according to the Phelan-McDermid Syndrome Foundation, yet few physicians have encountered the syndrome. While some clinical guidelines exist [24-28], comprehensive medical assessment parameters have yet to be developed.

Clinically, there have been at least 13 case series published in the literature that describe approximately 584 affected individuals (see Tables 1 and 2), although several studies present overlapping cases and the majority of data has been collected using parent surveys [27,29-40]. Reports highlight a broad and clinically heterogeneous phenotype; clinical features consistently reported include global developmental delay, absent or severely delayed speech, autistic features, minor dysmorphic features, and hypotonia. Affected individuals are more likely to suffer from medical complications, such as gastrointestinal disease, renal abnormalities, upper respiratory tract infections, and seizures. Brain MRI studies suggest a higher than expected prevalence of arachnoid cysts, ventriculomegaly, dysmyelination, and morphological changes of the corpus callosum $[27,30,36,37,41]$. Recently, several case reports have also proposed a putative association between PMS and atypical bipolar disorder and progressive loss of skills during adolescence or adulthood [29,42,43]. Comprehensive mapping of the phenotype using systematic and prospective assessment was recently reported in a sample of 32 subjects highlighting the high prevalence of ASD in these patients, at $84 \%$ [37].

Several studies have also examined genotypephenotype correlations with conflicting results. [31-33,35,37,39,40,44,45]. Despite small sample sizes and methodological challenges, correlations have been observed between larger deletion sizes and minor dysmorphic features $[31,37,44]$, number of medical comorbidities [37], the Developmental Profile [45,46], hypotonia $[33,44]$, and the absence of an ASD diagnosis [44]. In contrast to the latter study, another study found that larger deletion sizes were associated with more severe socialcommunication impairments related to ASD [37], whereas others have found no association between deletion size and phenotypic severity [32,35].

While there is agreement about core deficits of PMS, there have been no established parameters to guide evaluation and medical monitoring of the syndrome. The objective of this paper is to make recommendations to assess the medical, genetic, and neurological features of PMS.

\section{Clinical genetics}

Genetic testing is necessary to confirm the presence of deletions or mutations in SHANK3. Chromosomal microarray analysis (CMA) should be done as a first-tier workup for any child with ASD or developmental delays [20-23]. CMA will ascertain the majority of PMS cases which most often result from deletions or other structural rearrangements resulting in copy number loss of varying size on $22 \mathrm{q} 13$ but will not identify patients with pathogenic SHANK3 variants or smaller intragenic deletions or duplications which disrupt gene function [30]. Deletions at $22 \mathrm{q} 13$ occur de novo in the majority of patients although in $20 \%$ of cases, a parent carries a balanced rearrangement [45], hence there is significant risk of recurrence in some families. For this reason, chromosome analysis should be performed in conjunction with positive CMA findings to explore the presence of ring chromosome 22 and translocations. Biological parents should be tested with fluorescence in situ hybridization (FISH) to rule out a translocation or inversion in order to determine heritability and risk of recurrence within families. A balanced translocation or inversion involving chromosome 22 in a parent significantly increases the risk of recurrence in families and siblings of the proband should be tested when relevant [47-50]. There have been several reports of probands with apparently de novo deletions with siblings with identical deletions, likely resulting from germline mosaicism in a parent $[4,42,51]$. Thus, although the recurrence risk for future pregnancies is low for apparently de novo deletions, it is marginally greater than in the general population because parents may have germline mosaicism. Finally, for cases where PMS is part of the differential diagnosis, Sanger or next generation sequencing should be used to test for SHANK3 mutations if CMA and karyotyping are unrevealing. In addition, it should be noted that several clinical laboratories offer autism sequencing panels which include the SHANK3 gene. In this situation, it is important to determine whether the clinical laboratory offers complete sequencing of the SHANK3 gene. Indeed, SHANK3 is one of the most GCrich genes in the genome, and reliable sequencing requires considerable optimization. Supplemental testing by multiplex ligation-dependent probe amplification (MLPA) or other dosage-sensitive methods for detection of smaller intragenic deletions and duplications below the resolution of CMA may be considered as some clinical laboratories will include these after a negative sequencing result.

Clinical genetics evaluations and dysmorphology exams should be performed by a clinical geneticist to assess growth, pubertal development, head size, craniofacial features, digits, extremities, chest, spine, skin, and screen for 
Table 1 Dysmorphic features associated with PMS

\begin{tabular}{|c|c|c|c|c|c|c|c|c|c|c|c|c|c|c|}
\hline Sparse hair/abnormal whorl & $\mathrm{n} / \mathrm{a}$ & $\begin{array}{l}n=31 \\
\mathrm{n} / \mathrm{a}\end{array}$ & $\begin{array}{l}n=33 \\
n / a\end{array}$ & $\begin{array}{l}n=11 \\
\mathrm{n} / \mathrm{a}\end{array}$ & $\begin{array}{l}n=9 \\
n / a\end{array}$ & $\begin{array}{l}n=30 \\
n / a\end{array}$ & $\begin{array}{l}n=10 / \\
n / a\end{array}$ & $\begin{array}{l}n=13 \\
n / a\end{array}$ & $\begin{array}{l}n=43 \\
n / a\end{array}$ & n/a & $\mathrm{n} / \mathrm{a}$ & $16 \%(5 / 32)$ & $\mathrm{n} / \mathrm{a}$ & 16 \\
\hline Macrocephaly & $\mathrm{n} / \mathrm{a}$ & $\mathrm{n} / \mathrm{a}$ & $n / a$ & $n / a$ & $\mathrm{n} / \mathrm{a}$ & $7 \%(2 / 30)$ & $\mathrm{n} / \mathrm{a}$ & $\mathrm{n} / \mathrm{a}$ & $21 \%(9 / 43)$ & $\mathrm{n} / \mathrm{a}$ & $23 \%(11 / 47)$ & $31 \%(10 / 32)$ & $18 \%(20 / 110)$ & 17 \\
\hline Microcephaly & $\mathrm{n} / \mathrm{a}$ & $\mathrm{n} / \mathrm{a}$ & n/a & $\mathrm{n} / \mathrm{a}$ & $\mathrm{n} / \mathrm{a}$ & $13 \%(4 / 30)$ & $\mathrm{n} / \mathrm{a}$ & $\mathrm{n} / \mathrm{a}$ & $11 \%(5 / 43)$ & $\mathrm{n} / \mathrm{a}$ & $14 \%(6 / 42)$ & $6 \%(2 / 32)$ & $11 \%(12 / 110)$ & 12 \\
\hline Dolichocephaly & $86 \%(6 / 7)$ & $57 \%(21 / 37)$ & $n / a$ & $n / a$ & $0 \%(0 / 9)$ & $23 \%(7 / 30)$ & $30 \%(32 / 107)$ & $\mathrm{n} / \mathrm{a}$ & $\mathrm{n} / \mathrm{a}$ & $\mathrm{n} / \mathrm{a}$ & $30 \%(16 / 54)$ & $25 \%(8 / 32)$ & $32 \%(36 / 113)$ & 37 \\
\hline Periorbital fullness & $\mathrm{n} / \mathrm{a}$ & $\mathrm{n} / \mathrm{a}$ & $n / a$ & $45 \%(5 / 11)$ & $n / a$ & $60 \%(18 / 30)$ & $\mathrm{n} / \mathrm{a}$ & $\mathrm{n} / \mathrm{a}$ & $\mathrm{n} / \mathrm{a}$ & $\mathrm{n} / \mathrm{a}$ & $n / a$ & $25 \%(8 / 32)$ & $55 \%(60 / 109)$ & 46 \\
\hline Epicanthal folds & $57 \%(4 / 7)$ & $41 \%(15 / 37)$ & $n / a$ & $73 \%(8 / 11)$ & $\mathrm{n} / \mathrm{a}$ & $37 \%(11 / 30)$ & $30 \%(32 / 107)$ & $70 \%(9 / 13)$ & $\mathrm{n} / \mathrm{a}$ & $\mathrm{n} / \mathrm{a}$ & n/a & $31 \%(10 / 32)$ & $47 \%(52 / 111)$ & 48 \\
\hline Ptosis & $43 \%(3 / 7)$ & $57 \%(21 / 37)$ & n/a & $n / a$ & $0 \%$ & $\mathrm{n} / \mathrm{a}$ & $23 \%(25 / 107)$ & $\mathrm{n} / \mathrm{a}$ & $\mathrm{n} / \mathrm{a}$ & $\mathrm{n} / \mathrm{a}$ & $\mathrm{n} / \mathrm{a}$ & $3 \%(1 / 32)$ & $47 \%(53 / 112)$ & 29 \\
\hline Deep set eyes & $\mathrm{n} / \mathrm{a}$ & $\mathrm{n} / \mathrm{a}$ & n/a & $n / a$ & $\mathrm{n} / \mathrm{a}$ & $\mathrm{n} / \mathrm{a}$ & $\mathrm{n} / \mathrm{a}$ & $\mathrm{n} / \mathrm{a}$ & $\mathrm{n} / \mathrm{a}$ & $14 \%(1 / 7)$ & $\mathrm{n} / \mathrm{a}$ & $6 \%(2 / 32)$ & $31 \%(34 / 111)$ & 19 \\
\hline Long eyelashes & $\mathrm{n} / \mathrm{a}$ & $\mathrm{n} / \mathrm{a}$ & $n / a$ & $45 \%(5 / 11)$ & $\mathrm{n} / \mathrm{a}$ & $37 \%(11 / 30)$ & $\mathrm{n} / \mathrm{a}$ & $\mathrm{n} / \mathrm{a}$ & $\mathrm{n} / \mathrm{a}$ & $\mathrm{n} / \mathrm{a}$ & $\mathrm{n} / \mathrm{a}$ & $44 \%(14 / 32)$ & $93 \%(105 / 113)$ & 58 \\
\hline Hypertelorism & $\mathrm{n} / \mathrm{a}$ & $\mathrm{n} / \mathrm{a}$ & n/a & $36 \%(4 / 11)$ & $n / a$ & $17 \%(5 / 30)$ & $\mathrm{n} / \mathrm{a}$ & $\mathrm{n} / \mathrm{a}$ & $\mathrm{n} / \mathrm{a}$ & $\mathrm{n} / \mathrm{a}$ & $n / a$ & $13 \%(4 / 32)$ & $\mathrm{n} / \mathrm{a}$ & 22 \\
\hline Wide nasal bridge & $\mathrm{n} / \mathrm{a}$ & $\mathrm{n} / \mathrm{a}$ & $n / a$ & $n / a$ & $\mathrm{n} / \mathrm{a}$ & $\mathrm{n} / \mathrm{a}$ & $\mathrm{n} / \mathrm{a}$ & $\mathrm{n} / \mathrm{a}$ & $\mathrm{n} / \mathrm{a}$ & $\mathrm{n} / \mathrm{a}$ & $n / a$ & $16 \%(5 / 32)$ & $\mathrm{n} / \mathrm{a}$ & 16 \\
\hline Bulbous nose & $\mathrm{n} / \mathrm{a}$ & $\mathrm{n} / \mathrm{a}$ & $\mathrm{n} / \mathrm{a}$ & $\mathrm{n} / \mathrm{a}$ & $n / a$ & $80 \%(24 / 30)$ & $\mathrm{n} / \mathrm{a}$ & $70 \%(9 / 13)$ & $\mathrm{n} / \mathrm{a}$ & $\mathrm{n} / \mathrm{a}$ & $61 \%(33 / 54)$ & $47 \%(15 / 32)$ & $\mathrm{n} / \mathrm{a}$ & 65 \\
\hline Low set ears & $\mathrm{n} / \mathrm{a}$ & $\mathrm{n} / \mathrm{a}$ & $n / a$ & $\mathrm{n} / \mathrm{a}$ & $\mathrm{n} / \mathrm{a}$ & $7 \%(2 / 30)$ & $\mathrm{n} / \mathrm{a}$ & $\mathrm{n} / \mathrm{a}$ & $\mathrm{n} / \mathrm{a}$ & $14 \%(1 / 7)$ & $\mathrm{n} / \mathrm{a}$ & $3 \%(1 / 32)$ & $\mathrm{n} / \mathrm{a}$ & 5 \\
\hline Ear anomalies & $86 \%(6 / 7)$ & $65 \%(24 / 37)$ & $82 \%(27 / 33)$ & $27 \%(3 / 11)$ & $67 \%(6 / 9)$ & $73 \%(22 / 30)$ & $54 \%(58 / 107)$ & $70 \%(9 / 13)$ & $\mathrm{n} / \mathrm{a}$ & $\mathrm{n} / \mathrm{a}$ & $n / a$ & $41 \%(13 / 32)$ & $\mathrm{n} / \mathrm{a}$ & 63 \\
\hline Full lips & $\mathrm{n} / \mathrm{a}$ & $\mathrm{n} / \mathrm{a}$ & $n / a$ & n/a & $\mathrm{n} / \mathrm{a}$ & $\mathrm{n} / \mathrm{a}$ & $\mathrm{n} / \mathrm{a}$ & $\mathrm{n} / \mathrm{a}$ & $\mathrm{n} / \mathrm{a}$ & $\mathrm{n} / \mathrm{a}$ & n/a & $31 \%(10 / 32)$ & $\mathrm{n} / \mathrm{a}$ & 31 \\
\hline High arched palate & $\mathrm{n} / \mathrm{a}$ & $\mathrm{n} / \mathrm{a}$ & $n / a$ & $n / a$ & $n / a$ & $\mathrm{n} / \mathrm{a}$ & $\mathrm{n} / \mathrm{a}$ & $\mathrm{n} / \mathrm{a}$ & $\mathrm{n} / \mathrm{a}$ & $\mathrm{n} / \mathrm{a}$ & $n / a$ & $25 \%(8 / 32)$ & $47 \%(49 / 104)$ & 36 \\
\hline Long philtrum & $\mathrm{n} / \mathrm{a}$ & $\mathrm{n} / \mathrm{a}$ & $n / a$ & $n / a$ & $\mathrm{n} / \mathrm{a}$ & $\mathrm{n} / \mathrm{a}$ & $\mathrm{n} / \mathrm{a}$ & $\mathrm{n} / \mathrm{a}$ & $\mathrm{n} / \mathrm{a}$ & $\mathrm{n} / \mathrm{a}$ & $n / a$ & $16 \%(5 / 32)$ & $\mathrm{n} / \mathrm{a}$ & 16 \\
\hline $\begin{array}{l}\text { Malocclusion/widely } \\
\text { spaced teeth }\end{array}$ & $\mathrm{n} / \mathrm{a}$ & $\mathrm{n} / \mathrm{a}$ & $n / a$ & $\mathrm{n} / \mathrm{a}$ & n/a & $\mathrm{n} / \mathrm{a}$ & $\mathrm{n} / \mathrm{a}$ & $\mathrm{n} / \mathrm{a}$ & $\mathrm{n} / \mathrm{a}$ & $\mathrm{n} / \mathrm{a}$ & $\mathrm{n} / \mathrm{a}$ & $19 \%(6 / 32)$ & $\mathrm{n} / \mathrm{a}$ & 19 \\
\hline Micrognathia & $\mathrm{n} / \mathrm{a}$ & $\mathrm{n} / \mathrm{a}$ & n/a & $\mathrm{n} / \mathrm{a}$ & $\mathrm{n} / \mathrm{a}$ & $10 \%(3 / 30)$ & $\mathrm{n} / \mathrm{a}$ & $\mathrm{n} / \mathrm{a}$ & $\mathrm{n} / \mathrm{a}$ & $\mathrm{n} / \mathrm{a}$ & $n / a$ & $13 \%(4 / 32)$ & $\mathrm{n} / \mathrm{a}$ & 12 \\
\hline Full cheeks & $\mathrm{n} / \mathrm{a}$ & $\mathrm{n} / \mathrm{a}$ & $n / a$ & $\mathrm{n} / \mathrm{a}$ & $\mathrm{n} / \mathrm{a}$ & $\mathrm{n} / \mathrm{a}$ & $\mathrm{n} / \mathrm{a}$ & $\mathrm{n} / \mathrm{a}$ & $\mathrm{n} / \mathrm{a}$ & $\mathrm{n} / \mathrm{a}$ & n/a & $25 \%(8 / 32)$ & $\mathrm{n} / \mathrm{a}$ & 25 \\
\hline Malar hypoplasia & $\mathrm{n} / \mathrm{a}$ & $\mathrm{n} / \mathrm{a}$ & n/a & $\mathrm{n} / \mathrm{a}$ & $\mathrm{n} / \mathrm{a}$ & $\mathrm{n} / \mathrm{a}$ & $\mathrm{n} / \mathrm{a}$ & $\mathrm{n} / \mathrm{a}$ & $\mathrm{n} / \mathrm{a}$ & $\mathrm{n} / \mathrm{a}$ & $\mathrm{n} / \mathrm{a}$ & $9 \%(3 / 32)$ & $\mathrm{n} / \mathrm{a}$ & 9 \\
\hline Flat midface & $\mathrm{n} / \mathrm{a}$ & $\mathrm{n} / \mathrm{a}$ & $n / a$ & n/a & n/a & $\mathrm{n} / \mathrm{a}$ & $\mathrm{n} / \mathrm{a}$ & $\mathrm{n} / \mathrm{a}$ & $\mathrm{n} / \mathrm{a}$ & $\mathrm{n} / \mathrm{a}$ & n/a & $3 \%(1 / 32)$ & $\mathrm{n} / \mathrm{a}$ & 3 \\
\hline Pointed chin & $\mathrm{n} / \mathrm{a}$ & $62 \%(23 / 37)$ & n/a & $n / a$ & $56 \%(5 / 9)$ & $\mathrm{n} / \mathrm{a}$ & $27 \%(29 / 107)$ & $\mathrm{n} / \mathrm{a}$ & $\mathrm{n} / \mathrm{a}$ & $\mathrm{n} / \mathrm{a}$ & $n / a$ & $22 \%(7 / 32)$ & $52 \%(58 / 111)$ & 44 \\
\hline Fifth finger clinodactyly & $\mathrm{n} / \mathrm{a}$ & $14 \%(5 / 37)$ & n/a & $n / a$ & $\mathrm{n} / \mathrm{a}$ & $\mathrm{n} / \mathrm{a}$ & $\mathrm{n} / \mathrm{a}$ & $\mathrm{n} / \mathrm{a}$ & $\mathrm{n} / \mathrm{a}$ & $\mathrm{n} / \mathrm{a}$ & $\mathrm{n} / \mathrm{a}$ & $9 \%(3 / 32)$ & $\mathrm{n} / \mathrm{a}$ & 12 \\
\hline Large fleshy hands & $\mathrm{n} / \mathrm{a}$ & $68 \%(25 / 37)$ & $n / a$ & $\mathrm{n} / \mathrm{a}$ & $56 \%(5 / 9)$ & $47 \%(14 / 30)$ & $33 \%(35 / 107)$ & $46 \%(6 / 13)$ & $\mathrm{n} / \mathrm{a}$ & $\mathrm{n} / \mathrm{a}$ & $55 \%(29 / 53)$ & $53 \%(17 / 32)$ & $63 \%(71 / 112)$ & 53 \\
\hline $\begin{array}{l}\text { Hypoplastic/dysplastic } \\
\text { nails }\end{array}$ & $\mathrm{n} / \mathrm{a}$ & $78 \%(29 / 37)$ & n/a & $27 \%(3 / 11)$ & $56 \%(5 / 9)$ & $3 \%(1 / 30)$ & $36 \%(39 / 107)$ & $23 \%(3 / 13)$ & $\mathrm{n} / \mathrm{a}$ & $\mathrm{n} / \mathrm{a}$ & $75 \%(40 / 53)$ & $34 \%(11 / 32)$ & $73 \%(81 / 111)$ & 45 \\
\hline Hyper-extensibility & $\mathrm{n} / \mathrm{a}$ & $\mathrm{n} / \mathrm{a}$ & $n / a$ & $\mathrm{n} / \mathrm{a}$ & $\mathrm{n} / \mathrm{a}$ & $\mathrm{n} / \mathrm{a}$ & $\mathrm{n} / \mathrm{a}$ & $\mathrm{n} / \mathrm{a}$ & $\mathrm{n} / \mathrm{a}$ & $\mathrm{n} / \mathrm{a}$ & $\mathrm{n} / \mathrm{a}$ & $25 \%(8 / 32)$ & $61 \%(68 / 111)$ & 86 \\
\hline Abnormal spine curvature & $\mathrm{n} / \mathrm{a}$ & $\mathrm{n} / \mathrm{a}$ & $\mathrm{n} / \mathrm{a}$ & $\mathrm{n} / \mathrm{a}$ & $n / a$ & $\mathrm{n} / \mathrm{a}$ & $\mathrm{n} / \mathrm{a}$ & $\mathrm{n} / \mathrm{a}$ & $n / a$ & $\mathrm{n} / \mathrm{a}$ & $n / a$ & $22 \%(7 / 32)$ & $\mathrm{n} / \mathrm{a}$ & 22 \\
\hline Sacral dimple & $\mathrm{n} / \mathrm{a}$ & $\mathrm{n} / \mathrm{a}$ & $n / a$ & n/a & $\mathrm{n} / \mathrm{a}$ & $\mathrm{n} / \mathrm{a}$ & $\mathrm{n} / \mathrm{a}$ & $\mathrm{n} / \mathrm{a}$ & $\mathrm{n} / \mathrm{a}$ & $\mathrm{n} / \mathrm{a}$ & $37 \%(19 / 52)$ & $13 \%(4 / 32)$ & $\mathrm{n} / \mathrm{a}$ & 25 \\
\hline $\begin{array}{l}\text { Syndactyly of } \\
\text { toes } 2 \text { and } 3\end{array}$ & $\mathrm{n} / \mathrm{a}$ & $38 \%(14 / 37)$ & $n / a$ & $45 \%(5 / 11)$ & $n / a$ & $43 \%(13 / 30)$ & $23 \%(25 / 107)$ & $\mathrm{n} / \mathrm{a}$ & $n / a$ & $\mathrm{n} / \mathrm{a}$ & $\mathrm{n} / \mathrm{a}$ & $9 \%(3 / 32)$ & $48 \%(53 / 110)$ & 34 \\
\hline
\end{tabular}

$\mathrm{n} / \mathrm{a}=$ not available.

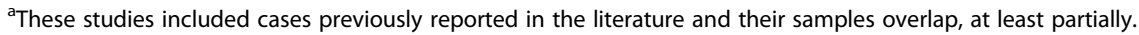


Table 2 Medical features associated with PMS

\begin{tabular}{|c|c|c|c|c|c|c|c|c|c|c|c|c|c|c|}
\hline Medical feature & $\begin{array}{l}\text { Nesslinger } \\
\text { et al. [35] }\end{array}$ & $\begin{array}{l}\text { Phelan } \\
\text { et al. [27] }\end{array}$ & $\begin{array}{l}\text { Luciani } \\
\text { et al. [33] }\end{array}$ & $\begin{array}{l}\text { Manning } \\
\text { et al. [34] }\end{array}$ & $\begin{array}{l}\text { Koolen } \\
\text { et al. [32] }\end{array}$ & $\begin{array}{l}\text { Jeffries } \\
\text { et al. [31] }\end{array}$ & $\begin{array}{l}\text { Cusmano- } \\
\text { Ozog et al. } \\
{[41]^{\mathrm{a}}}\end{array}$ & $\begin{array}{l}\text { Dhar } \\
\text { et al. } \\
\text { [30] }\end{array}$ & $\begin{array}{l}\text { Rollins } \\
{[38]^{\mathrm{a}}}\end{array}$ & $\begin{array}{l}\text { Denayer } \\
\text { et al. [29] }\end{array}$ & $\begin{array}{l}\text { Sarasua } \\
\text { et al. }[40]^{\text {a }}\end{array}$ & $\begin{array}{l}\text { Soorya } \\
\text { et al. [37] }\end{array}$ & $\begin{array}{l}\text { Sarasua } \\
\text { et al. [39] }\end{array}$ & $\begin{array}{l}\text { Average } \\
\text { (\%) }\end{array}$ \\
\hline & $n=7$ & $n=37$ & $n=33$ & $n=11$ & $n=9$ & $n=30$ & $n=107$ & $n=13$ & $n=43$ & $n=7$ & $n=54$ & $n=32$ & $n=201$ & \\
\hline Hypotonia & $100 \%(7 / 7)$ & $97 \%(36 / 37)$ & $82 \%(27 / 33)$ & $82 \%(9 / 11)$ & $89 \%(8 / 9)$ & $47 \%(14 / 30)$ & $86 \%(92 / 107)$ & $31 \%(4 / 13)$ & $\mathrm{n} / \mathrm{a}$ & $29 \%(2 / 7)$ & $80 \%(48 / 60)$ & $75 \%(24 / 32)$ & $75 \%(82 / 110)$ & 73 \\
\hline Sleep disturbance & $\mathrm{n} / \mathrm{a}$ & $\mathrm{n} / \mathrm{a}$ & $\mathrm{n} / \mathrm{a}$ & $\mathrm{n} / \mathrm{a}$ & $\mathrm{n} / \mathrm{a}$ & $\mathrm{n} / \mathrm{a}$ & $\mathrm{n} / \mathrm{a}$ & $\mathrm{n} / \mathrm{a}$ & $\mathrm{n} / \mathrm{a}$ & $\mathrm{n} / \mathrm{a}$ & $\mathrm{n} / \mathrm{a}$ & $41 \%(13 / 32)$ & $46 \%(12 / 26)$ & 44 \\
\hline $\begin{array}{l}\text { Gastroesophageal } \\
\text { reflux }\end{array}$ & $n / a$ & $\mathrm{n} / \mathrm{a}$ & $\mathrm{n} / \mathrm{a}$ & $\mathrm{n} / \mathrm{a}$ & $\mathrm{n} / \mathrm{a}$ & $\mathrm{n} / \mathrm{a}$ & $\mathrm{n} / \mathrm{a}$ & $\mathrm{n} / \mathrm{a}$ & $\mathrm{n} / \mathrm{a}$ & $\mathrm{n} / \mathrm{a}$ & $\mathrm{n} / \mathrm{a}$ & $44 \%(14 / 32)$ & $42 \%(62 / 149)$ & 43 \\
\hline $\begin{array}{l}\text { Increased pain } \\
\text { tolerance }\end{array}$ & $\mathrm{n} / \mathrm{a}$ & $\mathrm{n} / \mathrm{a}$ & $\mathrm{n} / \mathrm{a}$ & $0 \%$ & $\mathrm{n} / \mathrm{a}$ & $10 \%(3 / 30)$ & $31 \%(33 / 107)$ & $n / a$ & $n / a$ & $\mathrm{n} / \mathrm{a}$ & $n / a$ & $88 \%(28 / 32)$ & $77 \%(131 / 170)$ & 42 \\
\hline $\begin{array}{l}\text { Constipation/ } \\
\text { diarrhea }\end{array}$ & $n / a$ & $\mathrm{n} / \mathrm{a}$ & $n / a$ & $\mathrm{n} / \mathrm{a}$ & $\mathrm{n} / \mathrm{a}$ & $\mathrm{n} / \mathrm{a}$ & $\mathrm{n} / \mathrm{a}$ & $\mathrm{n} / \mathrm{a}$ & $n / a$ & $\mathrm{n} / \mathrm{a}$ & $\mathrm{n} / \mathrm{a}$ & $38 \%(12 / 32)$ & $41 \%(11 / 27)$ & 40 \\
\hline $\begin{array}{l}\text { Brain imaging } \\
\text { abnormalities }\end{array}$ & $14 \%(1 / 7)$ & $\mathrm{n} / \mathrm{a}$ & $\mathrm{n} / \mathrm{a}$ & $9 \%(2 / 23)$ & $\mathrm{n} / \mathrm{a}$ & $7 \%(2 / 30)$ & $\mathrm{n} / \mathrm{a}$ & $56 \%(5 / 9)$ & $\mathrm{n} / \mathrm{a}$ & $43 \%(3 / 7)$ & $\mathrm{n} / \mathrm{a}$ & $75 \%(21 / 28)$ & $19 \%(24 / 129)$ & 32 \\
\hline $\begin{array}{l}\text { Recurring upper } \\
\text { respiratory tract } \\
\text { infections }\end{array}$ & $\mathrm{n} / \mathrm{a}$ & $\mathrm{n} / \mathrm{a}$ & $\mathrm{n} / \mathrm{a}$ & $\mathrm{n} / \mathrm{a}$ & $\mathrm{n} / \mathrm{a}$ & $\mathrm{n} / \mathrm{a}$ & $n / a$ & $8 \%(1 / 13)$ & $n / a$ & $\mathrm{n} / \mathrm{a}$ & $n / a$ & $53 \%(17 / 32)$ & $n / a$ & 30 \\
\hline Renal abnormalities & $\mathrm{n} / \mathrm{a}$ & $\mathrm{n} / \mathrm{a}$ & $\mathrm{n} / \mathrm{a}$ & $\mathrm{n} / \mathrm{a}$ & $\mathrm{n} / \mathrm{a}$ & $17 \%(5 / 30)$ & $\mathrm{n} / \mathrm{a}$ & $n / a$ & $\mathrm{n} / \mathrm{a}$ & $\mathrm{n} / \mathrm{a}$ & $\mathrm{n} / \mathrm{a}$ & $38 \%(12 / 32)$ & $26 \%(39 / 148)$ & 27 \\
\hline Lymphedema & $29 \%(2 / 7)$ & $\mathrm{n} / \mathrm{a}$ & $\mathrm{n} / \mathrm{a}$ & $\mathrm{n} / \mathrm{a}$ & $\mathrm{n} / \mathrm{a}$ & $\mathrm{n} / \mathrm{a}$ & $\mathrm{n} / \mathrm{a}$ & $23 \%(3 / 13)$ & $\mathrm{n} / \mathrm{a}$ & $\mathrm{n} / \mathrm{a}$ & $\mathrm{n} / \mathrm{a}$ & $22 \%(7 / 32)$ & $24 \%(26 / 108)$ & 25 \\
\hline $\begin{array}{l}\text { Seizures (febrile } \\
\text { and/or non-febrile) }\end{array}$ & $14 \%(1 / 7)$ & $27 \%(10 / 37)$ & $24 \%(8 / 33)$ & $27 \%(3 / 11)$ & $\mathrm{n} / \mathrm{a}$ & $17 \%(5 / 30)$ & $23 \%(25 / 107)$ & $31 \%(4 / 13)$ & $n / a$ & $14 \%(1 / 7)$ & $19 \%(10 / 54)$ & $41 \%(13 / 32)$ & $27 \%(41 / 151)$ & 24 \\
\hline $\begin{array}{l}\text { Esotropia/ } \\
\text { strabismus }\end{array}$ & $n / a$ & $\mathrm{n} / \mathrm{a}$ & $n / a$ & $\mathrm{n} / \mathrm{a}$ & $n / a$ & $13 \%(4 / 30)$ & $\mathrm{n} / \mathrm{a}$ & $\mathrm{n} / \mathrm{a}$ & $\mathrm{n} / \mathrm{a}$ & $14 \%(1 / 7)$ & $25 \%(13 / 53)$ & $6 \%(2 / 32)$ & $26 \%(29 / 109)$ & 17 \\
\hline $\begin{array}{l}\text { Short stature/ } \\
\text { delayed growth }\end{array}$ & $0 \%(0 / 7)$ & $\mathrm{n} / \mathrm{a}$ & $12 \%(4 / 33)$ & $\mathrm{n} / \mathrm{a}$ & $\mathrm{n} / \mathrm{a}$ & $\mathrm{n} / \mathrm{a}$ & $11 \%(12 / 107)$ & $\mathrm{n} / \mathrm{a}$ & $12 \%(5 / 43)$ & $\mathrm{n} / \mathrm{a}$ & $13 \%(5 / 40)$ & $13 \%(4 / 32)$ & $11 \%(11 / 96)$ & 12 \\
\hline $\begin{array}{l}\text { Tall stature/ } \\
\text { accelerated } \\
\text { growth }\end{array}$ & $14 \%(1 / 7)$ & $\mathrm{n} / \mathrm{a}$ & $18 \%(6 / 33)$ & $\mathrm{n} / \mathrm{a}$ & $\mathrm{n} / \mathrm{a}$ & $7 \%(2 / 30)$ & $\mathrm{n} / \mathrm{a}$ & $\mathrm{n} / \mathrm{a}$ & $11 \%(5 / 43)$ & $\mathrm{n} / \mathrm{a}$ & $13 \%(5 / 40)$ & $3 \%(1 / 32)$ & $9 \%(9 / 96)$ & 11 \\
\hline Cardiac defects & $\mathrm{n} / \mathrm{a}$ & $\mathrm{n} / \mathrm{a}$ & $\mathrm{n} / \mathrm{a}$ & $\mathrm{n} / \mathrm{a}$ & $\mathrm{n} / \mathrm{a}$ & $13 \%(4 / 30)$ & $\mathrm{n} / \mathrm{a}$ & $\mathrm{n} / \mathrm{a}$ & $\mathrm{n} / \mathrm{a}$ & $\mathrm{n} / \mathrm{a}$ & $\mathrm{n} / \mathrm{a}$ & $3 \%(1 / 32)$ & $\mathrm{n} / \mathrm{a}$ & 8 \\
\hline $\begin{array}{l}\text { Precocious or } \\
\text { delayed puberty }\end{array}$ & $\mathrm{n} / \mathrm{a}$ & $\mathrm{n} / \mathrm{a}$ & $\mathrm{n} / \mathrm{a}$ & $\mathrm{n} / \mathrm{a}$ & $\mathrm{n} / \mathrm{a}$ & $\mathrm{n} / \mathrm{a}$ & $\mathrm{n} / \mathrm{a}$ & $\mathrm{n} / \mathrm{a}$ & $\mathrm{n} / \mathrm{a}$ & $\mathrm{n} / \mathrm{a}$ & $n / a$ & $0 \%(0 / 32)$ & $12 \%(15 / 121)$ & 6 \\
\hline Hypothyroidism & $\mathrm{n} / \mathrm{a}$ & $\mathrm{n} / \mathrm{a}$ & $\mathrm{n} / \mathrm{a}$ & $\mathrm{n} / \mathrm{a}$ & $n / a$ & $\mathrm{n} / \mathrm{a}$ & $n / a$ & $n / a$ & $n / a$ & $n / a$ & $n / a$ & $3 \%(1 / 32)$ & $6 \%(7 / 121)$ & 5 \\
\hline
\end{tabular}

$\mathrm{n} / \mathrm{a}=$ not available. 
organ malformations (such as congenital heart or renal defects). Most patients with PMS have at least one dysmorphic feature, although none are specific. The most common features are large fleshy hands, long eyelashes, pointed chin, prominent/dysplastic ears, bulbous nose, full lips, hypoplastic/dysplastic nails, and dolichocephaly (see Figure 1 and Table 1). All images are provided with guardian consent.

\section{Cognitive/behavioral assessment}

All patients with PMS should be referred to centers with expertise in developmental disorders for comprehensive cognitive, behavioral, and ASD evaluations. To date, clinical methods to assess the prevalence of ASD in PMS have varied significantly. Studies that prospectively evaluate ASD suggest rates from $0 \%(0 / 8)$ [36], 44\% (12/27) [31], 60\% (3/5) [30], 84\% (27/32) [37] to $94 \%(17 / 18)$ [27]. Of these studies, only Soorya and colleagues [37] used gold-standard diagnostic instruments-the Autism Diagnostic Interview-Revised and the Autism Diagnostic Observation Schedule. Given the limitations of ASDspecific diagnostic tools in individuals with significant ID, integrating careful clinical evaluation, caregiver reports, and structured direct observation is necessary in PMS. Cognitive assessments must likewise use standardized instruments appropriate for individuals with significant language delays and intellectual disability. Referrals for speech and language therapy, physical therapy, and occupational therapy evaluations should also be made. A diagnosis of ASD may aid in designing individualized educational and related service treatment plans and in justifying services through the board of education and insurance providers. Therapies should be delivered early and intensively given the severity of disability in many affected children. Because of significant learning and attention deficits in these patients, increased frequency of treatment with shorter duration of sessions may be favorable. While the cognitive and behavioral assessment of affected individuals is critical, it is nevertheless considered outside of the scope of this paper and will be addressed in subsequent recommendations.

\section{Neurology}

Neurological examinations should be conducted to evaluate gross motor skills and gait, fine motor coordination, cranial nerves, and deep tendon reflexes. In PMS, evidence supports the high prevalence of hypotonia (see Table 2), delays in achieving motor milestones, and inability to ambulate, among other motor deficits [27,30-34,36,37]. Feeding difficulties are a common early sign, possibly associated with hypotonia. Gait is almost uniformly affected in PMS, and abnormalities include steppage gait, toe walking, and variable degrees of broad-based ataxic gait. Careful assessment of this domain is important, as is appropriate referrals for pediatric physiatry, physical therapy, and orthopedics to explore the possibility of various interventions, including orthotics and bracing. Abnormality of posture, motor coordination and motor planning, though not specific to PMS, are almost invariably seen. There is also an increased risk of scoliosis. Given the broad array of motor deficits, low muscle tone and related feeding problems, physical, occupational, and feeding therapy should be initiated as early as possible. Screening for neuromuscular scoliosis should be performed at every

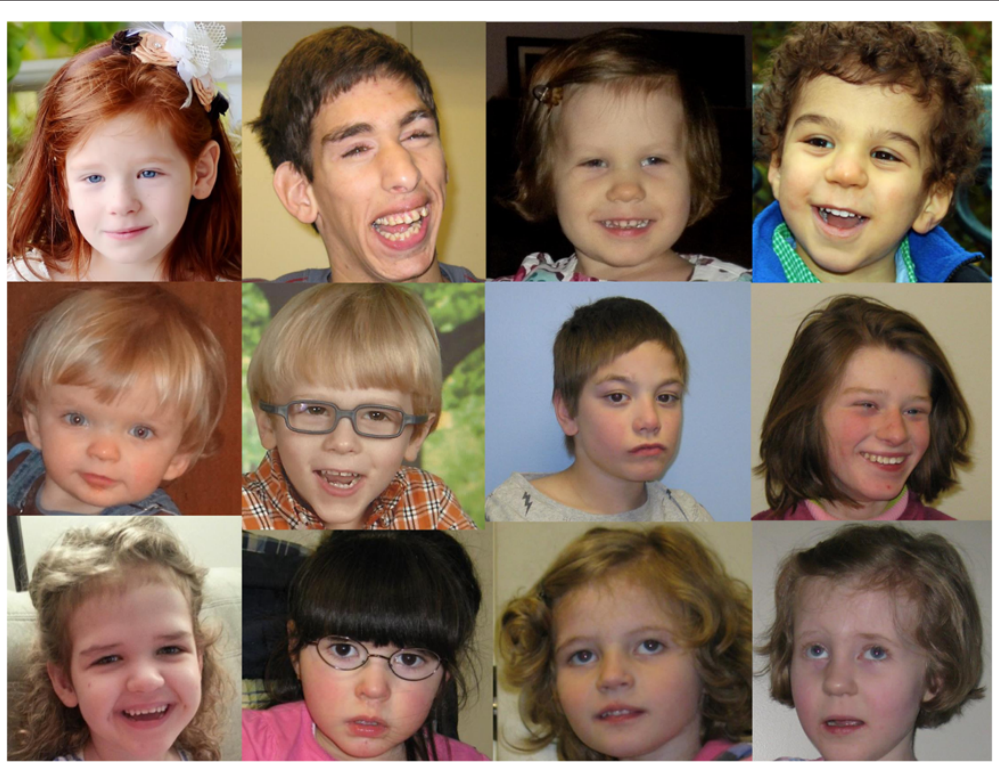

Figure 1 Images of individuals with Phelan-McDermid syndrome illustrating common dysmorphic facial features, including long eyelashes, bulbous nose, and pointed chin. All images are provided with guardian consent. 
routine visit. Head growth may also be abnormal, and some patients have macrocephaly (see Table 1); head circumference measurements should be performed routinely in PMS up to age 36 months.

\section{Seizure assessment}

Neurological phenotypic features are in need of further clarification in PMS, and few studies have reported electroencephalography (EEG) results. Most descriptions of PMS report higher than expected rates of seizure disorders; however, recording methods are not consistent and findings have not been well replicated. EEG recordings have not been prospectively collected in published studies of PMS, although existing case series report on the prevalence of seizure disorders using retrospective review and parent survey methods [27,30,31,33,36,37,39]. Prevalence estimates of seizure disorders range from $0 \%(0 / 8)$ [36] to $31 \%(4 / 13)$ [30], depending on the study. In a recent study, $41 \%$ (13/32) of participants had clinical seizures reported by parents, including $22 \%$ (7/32) with febrile seizures only, one participant with complex febrile seizures, and another patient who required temporal lobectomy due to uncontrolled seizure disorder [37]. Seizure disorders can be highly debilitating for affected children and families. Seizures have been associated with regression in some cases [36], in addition to at least one report of mortality due to seizure-induced aspiration [2]. Seizures have not been intractable in most patients with PMS, but there is no information about whether certain anticonvulsant medications are more effective than others for these individuals. Overnight video-EEG is therefore recommended using the standard 10-20 system and 64 inputs of online spike and seizure detection programs for automated detection. Brief recordings may be inadequate to detect changes in some patients and sedation may be required to get reliable recordings. While an overnight EEG is not always needed to establish the diagnosis, it can be helpful in determining the type of seizures and assist in treatment decisions. There should also be a low threshold for repeating an EEG with signs of behavioral changes or regression, including loss of motor skills.

\section{Brain imaging}

Most descriptions of PMS report higher than expected rates of structural brain changes. Among the published case series, a total of 59 patients have had brain imaging, either through prospective assessment $[30,36,52]$ or medical record review [34,37]. Brain abnormalities were evident in $73 \%(43 / 59)$ of the cases, ranging from $44 \%(4 / 11)$ [34] to $100 \%(10 / 10)$ [52]. Changes included thinning or hypoplasia of the corpus callosum in $36 \%$ of cases (21/59); white matter changes such as delayed myelination, generalized white matter atrophy, and nonspecific white matter hyperintensities in 39\% (23/59); ventricular dilatation in
$32 \%$ (19/59), and interventricular, cerebellar, or temporal sylvian arachnoid cysts in $14 \%(8 / 59)$. The most recent prospective study specifically examined cerebellar malformations in ten patients with PMS using magnetic brain imaging (MRI) and found evidence of cerebellar vermis hypoplasia in six subjects, including an enlarged cisterna magna in five [52]. There have also been several patients with neurofibromatosis type 2 (NF2) reported in the literature who have ring chromosome 22 with NF2 features such as multiple intracranial meningiomas or vestibular schwannomas [53,54]. Overall, there remains a paucity of data on the abnormal neural systems underlying this syndrome. Given the high prevalence of structural brain changes and that little is known about the neurobiology associated with PMS, brain imaging is recommended and routine monitoring may be indicated in some cases, depending on the abnormality. Specifically, new assessments of individuals affected with PMS should include structural MRI to assess morphology and to rule out the presence of cysts, and cerebellar, white matter, and corpus callosum abnormalities. It remains to be determined how frequently patients with PMS should have an MRI and how often monitoring should occur when indicated. While sedation is likely required to acquire meaningful imaging studies, the risks of the procedure must be balanced with the potential benefit, especially in the absence of clinical signs suggestive of structural pathology.

\section{Endocrinology}

There are no systematic studies describing endocrine abnormalities in patients with PMS. There have been reports of both short stature [27,29-31,33,37,40] and accelerated growth $[26,27,35,41]$. In a focused analysis of growth in 55 patients previously described by the Greenwood Genetic Center, Rollins [38] reported a larger than expected percentage of patients having short (11\%) and tall (11\%) stature $(<5$ th percentile and $>95$ th percentile, respectively), although the majority (78\%) fell within the normal range. Short stature, in particular, has been specifically associated with ring chromosome 22 in some reports [30,31,33], although this is not a consistent finding in the literature [37]. Head circumference has also been specifically examined in several studies [31,37-40], and individuals with PMS are more likely to have either microcephaly $[(<3$ rd percentile $)$ (6\%-14\% of cases, depending on the study) or macrocephaly [(>97th percentile) $(7 \%-31 \%$ of cases $)]$. Hypothyroidism was present in 1 of 32 (3\%) patients in one study [37] and 7 of 121 (6\%) in another [39]. Hypertrichosis has also been reported in at least two subjects $[37,55]$. Finally, there has been one case report of central diabetes insipidus in a 2day old infant worth noting given what little is published about endocrine abnormalities in PMS [56].

Endocrine abnormalities should be considered in all children with PMS and assessed when clinically indicated. 
Proper nutrition would be indicated from body mass index (BMI) measurement and should be carefully assessed as children with PMS may have restricted diets and may ingest non-food items. Behavioral changes consistent with thyroid dysregulation should also be considered, including changes in activity level, cognition, or motor skills, and thyroid panels should be obtained to rule out hypothyroidism. As children get older, the possibility of early or late puberty should also be explored and monitored if necessary. Incomplete puberty such as premature adrenarche or premature thelarche should be examined as it would be for all children. Only precocious puberty has been reported in one study as occurring in 15 of 121 cases (12\%) [39]. Menstruation can be particularly confusing and distressing for individuals with PMS, and hormonal cycling may contribute to behavioral changes in some children. Referral to endocrinology should be facilitated if specific endocrine abnormalities appear.

\section{Nephrology}

Renal abnormalities are considered relatively common in PMS, with reports suggesting rates as high as 38\% [37], but few studies have systematically examined the prevalence and none have used prospective methods. On comprehensive medical record review of 32 patients in one study [37], renal abnormalities included vesicoureteral reflux (13\%), hydronephrosis (13\%), renal agenesis (6\%), dysplastic kidney (3\%), and horseshoe kidneys and pyelectasis (3\%). Another study documented renal problems in 39 of 148 cases (26\%), including vesicoureteral reflux $(14 \%)$, frequent urinary tract infections $(8 \%)$, polycystic kidney (5\%), duplicate kidney (1\%), and dilated renal pelvis (5\%) [39]. In the only other study to specifically report the prevalence of renal abnormalities, they were described in the context of genitourinary abnormalities in general, with $17 \%$ of patients affected with neonatal urinary infection and malformed clitoris, vesicoureteral reflux, unilateral multicystic kidney, and "partial renal failure" of unknown cause [31]. In at least one child, a unilateral multicystic kidney and Wilms' tumor in the contralateral, unaffected kidney was detected using prenatal ultrasound [57]. As some of these genitourinary abnormalities may result in clinical disease and require treatment, it is recommended that all individuals with PMS have routine blood pressure measurement and renal and bladder sonography performed at the time of diagnosis and, if the sonogram is abnormal, be referred to a pediatric nephrologist or urologist for monitoring or treatment. Fetal sonography should not substitute for this study, as it is usually not performed after renal development is complete. Because sonography may be normal in cases of vesicoureteral reflux, urinary tract infection at a young age or recurrent urinary tract infections should also prompt nephrology or urology referral. Finally, for those with abnormal renal or bladder sonography or high blood pressure, urinalysis and kidney function blood tests (e.g., urea, creatinine, and electrolytes) should be obtained as the patient is being referred to expert care for additional guidance about specific ongoing monitoring recommendations.

\section{Cardiology}

The prevalence of congenital heart defects (CHD) in PMS is highly variable. Phelan and McDermid (2011) report CHD in more than $25 \%$ of patients; the most common reported defects include tricuspid valve regurgitation, atrial septal defect, patent ductus arteriosus, and total anomalous pulmonary return [24,41]. Soorya and colleagues [37] reported only one case with CHD (aortic regurgitation) in their series of 32 patients (3\%), and Jeffries and colleagues [31] reported 4 of 30 (13\%) cases to have CHD, two with patent ductus arteriosus and two with total anomalous pulmonary venous return. These reports are based on retrospective chart reviews and parent questionnaires, and there are no published data of systematic prospective evaluations for CHD in patients with PMS using standard of care methods. Because patients with PMS may have associated CHD that would necessitate medical and/or surgical intervention, we recommend a standard cardiac evaluation inclusive of a detailed exam, echocardiography, and electrocardiography as part of the initial evaluation in all patients with PMS.

\section{Gastroenterology}

Gastrointestinal symptoms are common in PMS and include gastroesophageal reflux disease (GERD), constipation, and diarrhea $[27,37,39,41]$. Rates are not consistently documented, but parent interview and medical record review of 32 cases suggest that GERD occurs in $44 \%$ of cases and constipation and/or diarrhea in 38\% [37]. Another study reported similar rates, with 62 of 149 patients (42\%) suffering from GERD and 11 of 27 (41\%) from constipation [39]. Cyclic vomiting has also been described in several patients $[25,41]$. Feeding difficulties are likewise common [30,37] and may be related to low muscle tone. There have also been two reported cases of fulminant autoimmune hepatitis in girls with PMS [58,59]. Gastrointestinal symptoms can be highly distressing and may manifest as appetite or behavioral changes in patients who cannot describe or identify their discomfort. Increased pain tolerance in PMS may further complicate the diagnosis of gastrointestinal disorders. Any change in appetite or behavior should raise suspicion of gastrointestinal distress. Dietary changes and bowel regimens should be considered with evidence of constipation and GERD may be treated empirically, depending on symptom patterns. Finally, chewing of non-food items and pica has 
been described in up to $50 \%$ of cases of PMS [25]. Severe chewing and pica may require the attention of a gastroenterologist and a referral for behavioral therapy.

\section{Primary care/developmental pediatrics}

In addition to the multitude of specialized medical features characteristic of PMS, affected individuals are also prone to immune system dysfunction, including recurring ear and upper respiratory tract infections, seasonal allergies, food allergies, and asthma [30,37,39]. Repeated upper respiratory tract infections in PMS may be related, at least partially, to low muscle tone and subsequent problems with airway and sputum clearance. There is also evidence from animal studies that SHANK3 protein may play a role in immune function, including immune cell signal transduction [60]. Children with PMS may suffer from immunological dysfunction based on case reports of autoimmune hepatitis [58,59], atopic dermatitis [61], and recurring staphylococcus skin infections with a history of cellulitis [37]. Sarasua and colleagues [39] found cellulitis in 9 out of 137 (7\%) patients. These conditions should be managed as they would in any other child, but recognizing them may be more challenging in PMS and warrant having a low threshold of suspicion for infections of all types. In addition, as with any child with developmental delays, early and aggressive referral to pediatric audiology and ophthalmology is important, especially as there have been case reports of PMS patients having hearing problems and vision problems including strabismus, myopia $[27,37,39]$, and retinitis pigmentosa in one case [32]. Lymphedema has also been reported in the literature, including in up to $24 \%$ of cases in one study [39] and represents an especially troubling symptom for patients $[27,30,35,37,39]$. Routine management is warranted although benefits can be challenging to achieve. Compression boots, pneumatic pumps, or referral to vascular surgery may be considered in some cases. Thermoregulatory problems have also been described, including decreased perspiration and heat intolerance. Finally, dental abnormalities such as malocclusion, are common and can be quite severe in some cases [37,41]. Orthodontic or surgical correction of malocclusion may be considered to reduce the risk of tooth decay and periodontal disease or relieve pressure on the temporomandibular joint.

\section{Conclusions}

Phelan-McDermid syndrome is a complex and heterogeneous syndrome. While considered rare, the advent of advanced genetic analytic methods into clinical practice will likely identify more cases, and clinicians will require knowledge about appropriate assessment, and eventually treatment. CMA is the first tier in genetic analysis in addition to chromosome analysis to clarify the presence of ring chromosome 22 and translocations. Parents should also be tested for balanced rearrangement to assess recurrence risk in families. Sequencing of the SHANK3 gene is necessary to identify mutations when CMA is unrevealing. Although SHANK3 is understood to be the critical gene in the deletion syndrome, responsible for the core phenotypic features of PMS [2-4,8,62,63], it is likely that other deleted genes contribute to the severity and additional phenotypic characteristics. Ongoing studies are focused on exploring genotype-phenotype correlations, and should relationships emerge, it may delineate a role for other genes and pathways in PMS. Further, genotype-phenotype associations may aid in medical monitoring and treatment planning if larger deletion sizes are associated with specific medical comorbidity or if greater impairments in language or motor skills might be predicted from genotype.

Point mutations disrupting only SHANK3 have been described in the literature and result in a similar phenotype, including ASD and ID [2-4,7,37,64,65]. However, given the small number of patients identified to date, the full spectrum of phenotypic features has not clearly been defined and whether these patients are at the same increased risk of medical comorbidities as patients with deletions that encompass many genes in the region remains an active area of research. As whole exome and whole genome sequencing become widespread, these approaches will likely become the first line analyses in cases of unexplained developmental delay. It is estimated that the rates of mutation of SHANK3 in ASD and developmental delay are in the same range as deletions [66], so PMS due to mutation in SHANK3 will be increasingly identified.

A thorough history and physical examination is clearly the first step in evaluation. While there are several common medical and dysmorphic features, it does not appear that, as of yet, any features are specific for the syndrome. Neurological deficits are common in PMS. Motor deficits in particular may affect the child's feeding and ability to thrive. The risk of seizures is greater in PMS and EEG is recommended, especially when there is evidence of skill regression. Given the prevalence of structural brain abnormalities in PMS, including arachnoid cysts, there should be a low threshold for performing brain imaging. The identification of specific brain abnormalities in PMS will aid in more thorough characterization and may provide a critical link between PMS and associated behavior. Furthermore, the creation of an accurate brain phenotype may be important for identifying biological markers of disease progression and possibly treatment response in the future. Endocrine, renal, cardiac, and gastrointestinal problems have all been reported in PMS and require assessment and monitoring. Other associated medical features include recurring infections that require standard management but may be more challenging to detect in PMS. Few primary care or developmental pediatricians have experience with PMS but will need to gain familiarity 
in order to play a critical role in coordinating care across subspecialties. It is equally crucial for the developmental pediatrician and other professionals involved in their care to support the family in advocating for the child's educational and emotional needs by making sure educators and therapy providers understand the syndrome and its associated features. Appropriate referrals to specialists should be initiated early and interventions implemented intensively.
Pediatric physiatry, physical therapy, occupational therapy, and orthopedics are among the specialists to explore the possibility of various interventions, including feeding therapy, orthotics, and bracing. All patients require referrals to specialized centers for cognitive, behavioral, and ASD evaluations (see Table 3).

Ongoing monitoring is crucial to track the disease course in PMS over time in order to better understand

Table 3 Summary of clinical recommendations for assessment

\begin{tabular}{|c|c|c|}
\hline Medical specialty & Common clinical features & Assessments \\
\hline \multirow[t]{6}{*}{ Clinical genetics } & Large fleshy hands & Dysmorphology exam \\
\hline & Bulbous nose & \\
\hline & Long eyelashes & \\
\hline & Prominent/dysplastic ears & \\
\hline & Hypoplastic/dysplastic nails & \\
\hline & Dolichocephaly & \\
\hline \multirow[t]{4}{*}{ Molecular genetics } & & Chromosomal microarray \\
\hline & & Chromosome analysis (to identify ring chromosomes) \\
\hline & & Sanger or next generation sequencing (for mutations) \\
\hline & & $\begin{array}{l}\text { Fluorescence in situ hybridization (to identify balanced } \\
\text { rearrangements in parents) }\end{array}$ \\
\hline Psychiatry & Autism spectrum disorder & Gold standard diagnostic assessments \\
\hline \multirow[t]{3}{*}{ Psychology } & Aberrant behavior & Psychiatric evaluation \\
\hline & Intellectual disability & Cognitive and adaptive behavior testing \\
\hline & Absent or delayed speech & Speech and language evaluation \\
\hline \multirow[t]{5}{*}{ Neurology } & Seizures & Overnight video electroencephalography \\
\hline & Structural brain abnormalities & Brain imaging and head circumference monitoring \\
\hline & Feeding difficulties & Feeding therapy evaluation \\
\hline & Hypotonia & Occupational and physical therapy evaluations \\
\hline & Motor skill deficits & \\
\hline \multirow[t]{3}{*}{ Endocrinology } & Short/tall stature & Monitor height, weight, and body mass index \\
\hline & Hypothyroidism & Metabolic work-up, including thyroid function \\
\hline & & Nutritional assessment \\
\hline \multirow[t]{4}{*}{ Nephrology } & Vesicoureteral reflux & Renal and bladder ultrasonography \\
\hline & Urinary tract infections & Voiding cystourethrogram \\
\hline & Hydronephrosis & Monitoring of blood pressure \\
\hline & Renal cysts, hypoplasia, or agenesis & \\
\hline \multirow[t]{2}{*}{ Cardiology } & Congenital heart defects & Electrocardiography \\
\hline & & Echocardiography \\
\hline \multirow[t]{3}{*}{ Gastroenterology } & Gastroesophageal reflux & Referral for dietary changes and/or medication \\
\hline & Constipation/diarrhea & Bowel regimens \\
\hline & Pica & Referral to behavioral therapy \\
\hline \multirow[t]{6}{*}{ Primary care/developmental pediatrics } & Upper respiratory tract infections & Careful and consistent monitoring and management \\
\hline & Recurring ear infections & $\begin{array}{l}\text { Referral to otolaryngology, ophthalmology, physiatry, } \\
\text { dental, and orthopedics }\end{array}$ \\
\hline & Hearing and vision problems & \\
\hline & Lymphedema & \\
\hline & Dental problems & \\
\hline & Decreased perspiration/heat intolerance & \\
\hline
\end{tabular}


disease outcomes. There may be several developmental time points associated with increased risk of seizures, for example, and repeated assessments are necessary in suspected cases. In PMS, as patients age, they may be at increased risk for atypical bipolar disorder [29,42,43], and significant regression has also been reported in language, behavioral symptoms, motor skills, and selfhelp skills $[2,29,37,42,43,62]$. Isolated reports have also emerged recently describing mortality associated with complications of PMS, including seizure-induced aspiration [2], renal failure in a patient with unilateral renal agenesis [62], and pneumonia [42]. Awareness of the full scope of medical comorbidity and aggressive monitoring will be critical to ensure quality of life and survival of patients with PMS.

In summary, comprehensive assessment and regular monitoring of patients with PMS across organ systems are necessary to clarify the extent and severity of the phenotype and to understand how PMS develops over time. Appropriate evaluations may also provide important information on targets for early intervention and disease prevention in order to further develop the best clinical practices. Establishing the natural history of PMS is also a important step toward designing effective clinical trials and may support the advancement of multiple therapeutic possibilities in the future.

\section{Abbreviations}

ASD: autism spectrum disorder; BMl: body mass index; CMA: chromosomal microarray analysis; CHD: congenital heart defects;

EEG: electroencephalography; FISH: fluorescence in situ hybridization; GERD: gastroesophageal reflux disease; ID: intellectual disability; PMS: PhelanMcDermid syndrome; MRI: magnetic resonance imaging.

\section{Competing interests}

JDB has a patent on IGF1 treatment for Phelan-McDermid syndrome. All the other authors declare that they have no competing interests.

\section{Authors' contributions}

$A K, B A, A Y$, and $C F$ contributed to literature review and manuscript preparation. LB, ATW, YF, RR, JS, SS, LJE, and JDB contributed to the manuscript preparation. All authors read and approved the final manuscript.

\section{Acknowledgements}

This work was supported by grants from the Beatrice and Samuel A. Seaver Foundation and the National Institute of Mental Health (MH100276-01 to AK and MH089025 to JDB). We would like to thank Dr. Catalina Betancur for her scholarly review and valued edits to the manuscript and Dr. Katy Phelan for her review and suggestions. We would also like to thank the many families that work closely with us to better understand neurodevelopmental disability.

\section{Resources}

Physicians, other health professionals, and families can find more information about PMS through the Phelan-McDermid Syndrome Foundation at http://22q13.org or the Seaver Autism Center at Mount Sinai at http://www.shank3gene.org/.

\section{Author details}

${ }^{1}$ Seaver Autism Center for Research and Treatment, Icahn School of Medicine at Mount Sinai, One Gustave L. Levy Place, New York, NY 10029, USA. ${ }^{2}$ Department of Psychiatry, Icahn School of Medicine at Mount Sinai, One Gustave L. Levy Place, New York, NY 10029, USA. ${ }^{3}$ Department of Pediatrics,
Icahn School of Medicine at Mount Sinai, One Gustave L. Levy Place, New York, NY 10029, USA. ${ }^{4}$ Department of Neuroscience, Icahn School of Medicine at Mount Sinai, One Gustave L. Levy Place, New York, NY 10029, USA. ${ }^{5}$ Department of Neurology, Icahn School of Medicine at Mount Sinai, One Gustave L. Levy Place, New York, NY 10029, USA. ${ }^{6}$ Department of Genetics and Genomic Sciences, Icahn School of Medicine at Mount Sinai, One Gustave L. Levy Place, New York, NY 10029, USA. Division of Endocrinology and Diabetes, Icahn School of Medicine at Mount Sinai, One Gustave L. Levy Place, New York, NY 10029, USA. ${ }^{8}$ Department of Cardiology, Icahn School of Medicine at Mount Sinai, One Gustave L. Levy Place, New York, NY 10029, USA. 'Division of Behavioral Pediatrics, Icahn School of Medicine at Mount Sinai, One Gustave L. Levy Place, New York, NY 10029, USA. ${ }^{10}$ Friedman Brain Institute, Icahn School of Medicine at Mount Sinai, One Gustave L. Levy Place, New York, NY 10029, USA. "11Mindich Child Health and Development Institute, Icahn School of Medicine at Mount Sinai, One Gustave L. Levy Place, New York, NY 10029, USA.

Received: 15 July 2014 Accepted: 13 September 2014 Published: 8 October 2014

\section{References}

1. Leblond CS, Nava C, Polge A, Gauthier J, Huguet G, Lumbroso S, Giuliano F, Stordeur C, Depienne C, Mouzat K, Pinto D, Howe J, Lemière N, Durand CM, Guibert J, Ey E, Toro R, Peyre H, Mathieu A, Amsellem F, Rastam M, Gillberg IC, Rappold GA, Holt R, Monaco AP, Maestrini E, Galan P, Heron D, Jacquette A, Afenjar A, et al: Meta-analysis of SHANK mutations in autism spectrum disorders: a gradient of severity in cognitive impairments. PLoS Genet 2014, 10:e1004580.

2. Durand CM, Betancur C, Boeckers TM, Bockmann J, Chaste P, Fauchereau F, Nygren G, Rastam M, Gillberg IC, Anckarsäter H, Sponheim E, GoubranBotros H, Delorme R, Chabane N, Mouren-Simeoni MC, de Mas P, Bieth E, Rogé $B$, Héron D, Burglen L, Gillberg C, Leboyer M, Bourgeron T: Mutations in the gene encoding the synaptic scaffolding protein SHANK3 are associated with autism spectrum disorders. Nat Genet 2007, 39:25-27.

3. Gauthier J, Spiegelman D, Piton A, Lafrenière RG, Laurent S, St-Onge J, Lapointe L, Hamdan FF, Cossette P, Mottron L, Fombonne E, Joober R, Marineau C, Drapeau P, Rouleau GA: Novel de novo SHANK3 mutation in autistic patients. Am J Med Genet B Neuropsychiatr Genet 2009, 150B:421-424

4. Moessner R, Marshall CR, Sutcliffe JS, Skaug J, Pinto D, Vincent J, Zwaigenbaum L, Fernandez B, Roberts W, Szatmari P, Scherer SW: Contribution of SHANK3 mutations to autism spectrum disorder. Am J Hum Genet 2007, 81:1289-1297.

5. Pinto D, Delaby E, Merico D, Barbosa M, Merikangas A, Klei L, Thiruvahindrapuram B, Xu X, Ziman R, Wang Z, Vorstman JA, Thompson A, Regan R, Pilorge M, Pellecchia G, Pagnamenta AT, Oliveira B, Marshall CR, Magalhaes TR, Lowe JK, Howe JL, Griswold AJ, Gilbert J, Duketis E, Dombroski BA, De Jonge MV, Cuccaro M, Crawford EL, Correia CT, Conroy J, et al: Convergence of genes and cellular pathways dysregulated in autism spectrum disorders. Am J Hum Genet 2014, 94:677-694.

6. Cooper GM, Coe BP, Girirajan S, Rosenfeld JA, Vu TH, Baker C, Williams C, Stalker H, Hamid R, Hannig V, Abdel-Hamid H, Bader P, McCracken E, Niyazov D, Leppig K, Thiese H, Hummel M, Alexander N, Gorski J, Kussmann J, Shashi V, Johnson K, Rehder C, Ballif BC, Shaffer LG, Eichler EE: A copy number variation morbidity map of developmental delay. Nat Genet 2011, 43:838-846.

7. Gong X, Jiang YW, Zhang X, An Y, Zhang J, Wu Y, Wang J, Sun Y, Liu Y, Gao $X$, Shen Y, Wu X, Qiu Z, Jin L, Wu BL, Wang H: High proportion of 22q13 deletions and SHANK3 mutations in Chinese patients with intellectual disability. PLoS One 2012, 7:e34739.

8. Bonaglia MC, Giorda R, Mani E, Aceti G, Anderlid BM, Baroncini A, Pramparo $T$, Zuffardi O: Identification of a recurrent breakpoint within the SHANK3 gene in the 22q13.3 deletion syndrome. J Med Genet 2006, 43:822-828.

9. Boeckers TM: The postsynaptic density. Cell Tissue Res 2006, 326:409-422.

10. Darnell JC: Defects in translational regulation contributing to human cognitive and behavioral disease. Curr Opin Genet Dev 2011, 21:465-473.

11. Sakai Y, Shaw CA, Dawson BC, Dugas DV, Al-Mohtaseb Z, Hill DE, Zoghbi HY: Protein interactome reveals converging molecular pathways among autism disorders. Sci Trans/ Med 2011, 3:86ra49.

12. Bozdagi O, Sakurai T, Papapetrou D, Wang X, Dickstein DL, Takahashi N, Kajiwara Y, Yang M, Katz AM, Scattoni ML, Harris MJ, Saxena R, Silverman JL, 
Crawley JN, Zhou Q, Hof PR, Buxbaum JD: Haploinsufficiency of the autism-associated Shank3 gene leads to deficits in synaptic function, social interaction, and social communication. Mol Autism 2010, 1:15.

13. Kouser M, Speed HE, Dewey CM, Reimers JM, Widman AJ, Gupta N, Liu S, Jaramillo TC, Bangash M, Xiao B, Worley PF, Powell CM: Loss of predominant Shank3 isoforms results in hippocampus-dependent impairments in behavior and synaptic transmission. J Neurosci 2013, 33:18448-18468

14. Peça J, Feliciano C, Ting JT, Wang W, Wells MF, Venkatraman TN, Lascola $C D$, Fu Z, Feng G: Shank3 mutant mice display autistic-like behaviours and striatal dysfunction. Nature 2011, 472:437-442.

15. Raynaud F, Janossy A, Dahl J, Bertaso F, Perroy J, Varrault A, Vidal M, Worley PF, Boeckers TM, Bockaert J, Marin P, Fagni L, Homburger V: Shank3-rich2 interaction regulates AMPA receptor recycling and synaptic long-term potentiation. J Neurosci 2013, 33:9699-9715.

16. Wang X, McCoy PA, Rodriguiz RM, Pan Y, Je HS, Roberts AC, Kim CJ, Berrios J, Colvin JS, Bousquet-Moore D, Lorenzo I, Wu G, Weinberg RJ, Ehlers MD, Philpot BD, Beaudet AL, Wetsel WC, Jiang YH: Synaptic dysfunction and abnormal behaviors in mice lacking major isoforms of Shank3. Hum Mol Genet 2011, 20:3093-3108.

17. Yang M, Bozdagi O, Scattoni ML, Wöhr M, Roullet FI, Katz AM, Abrams DN, Kalikhman D, Simon H, Woldeyohannes L, Zhang JY, Harris MJ, Saxena R, Silverman JL, Buxbaum JD, Crawley JN: Reduced excitatory neurotransmission and mild autism-relevant phenotypes in adolescent Shank3 null mutant mice. J Neurosci 2012, 32:6525-6541

18. Bozdagi O, Tavassoli T, Buxbaum JD: Insulin-like growth factor-1 rescues synaptic and motor deficits in a mouse model of autism and developmental delay. Mol Autism 2013, 4:9.

19. Shcheglovitov A, Shcheglovitova O, Yazawa M, Portmann T, Shu R, Sebastiano V, Krawisz A, Froehlich W, Bernstein JA, Hallmayer JF, Dolmetsch RE: SHANK3 and IGF1 restore synaptic deficits in neurons from 22q13 deletion syndrome patients. Nature 2013, 503:267-271.

20. Manning M, Hudgins L, Professional Practice and Guidelines Committee: Array-based technology and recommendations for utilization in medical genetics practice for detection of chromosomal abnormalities. Genet Med 2010, 12:742-745.

21. Miller DT, Adam MP, Aradhya S, Biesecker LG, Brothman AR, Carter NP, Church DM, Crolla JA, Eichler EE, Epstein CJ, Faucett WA, Feuk L, Friedman JM, Hamosh A, Jackson L, Kaminsky EB, Kok K, Krantz ID, Kuhn RM, Lee C, Ostell JM, Rosenberg C, Scherer SW, Spinner NB, Stavropoulos DJ, Tepperberg JH, Thorland EC, Vermeesch JR, Waggoner DJ, Watson MS, et al: Consensus statement: chromosomal microarray is a first-tier clinical diagnostic test for individuals with developmental disabilities or congenital anomalies. Am J Hum Genet 2010, 86:749-764.

22. Schaefer GB, Mendelsohn NJ, Professional Practice and Guidelines Committee: Clinical genetics evaluation in identifying the etiology of autism spectrum disorders. Genet Med 2008, 10:301-305.

23. Schaefer GB, Mendelsohn NJ, Professional Practice and Guidelines Committee: Clinical genetics evaluation in identifying the etiology of autism spectrum disorders: 2013 guideline revisions. Genet Med 2013, 15:399-407.

24. Phelan K, Betancur C: Clinical utility gene card for: deletion 22q13 syndrome. Eur J Hum Genet 2011, 19(4). doi:10.1038/ejhg.2010.193. Epub 2010 Dec 8

25. Phelan K, McDermid HE: The 22q13.3 deletion syndrome (PhelanMcDermid syndrome). Mol Syndromol 2012, 2:186-201.

26. Phelan MC: Deletion 22q13.3 syndrome. Orphanet J Rare Dis 2008, 3:14 doi:10.1186/1750-1172-3-14.

27. Phelan MC, Rogers RC, Saul RA, Stapleton GA, Sweet K, McDermid H, Shaw SR, Claytor J, Willis J, Kelly DP: 22q13 deletion syndrome. Am J Med Genet 2001, 101:91-99.

28. Phelan K, Rogers C: Phelan-McDermid Syndrome, Gene Reviews [Internet]. Seattle: University of Washington; 2011.

29. Denayer A, Van Esch H, De Ravel T, Frijns JP, Van Buggenhout G, Vogels A, Devriendt K, Geutjens J, Thiry P, Swillen A: Neuropsychopathology in 7 patients with the $22 q 13$ deletion syndrome: presence of bipolar disorder and progressive loss of skills. Mol Syndromol 2012, 3:14-20.

30. Dhar SU, Del Gaudio D, German JR, Peters SU, Ou Z, Bader PI, Berg JS, Blazo M, Brown CW, Graham BH, Grebe TA, Lalani S, Irons M, Sparagana S, Williams M, Phillips JA III, Beaudet AL, Stankiewicz P, Patel A, Cheung SW Sahoo T: 22q13.3 deletion syndrome: clinical and molecular analysis using array CGH. Am J Med Genet A 2010, 152A:573-581.
31. Jeffries AR, Curran $S$, Elmslie F, Sharma A, Wenger $S$, Hummel M, Powell J: Molecular and phenotypic characterization of ring chromosome 22. Am J Med Genet A 2005, 137:139-147.

32. Koolen DA, Reardon W, Rosser EM, Lacombe D, Hurst JA, Law CJ, Bongers EM, Van Ravenswaaij-Arts CM, Leisink MA, Van Kessel AG, Veltman JA, De Vries BB: Molecular characterisation of patients with subtelomeric 22q abnormalities using chromosome specific array-based comparative genomic hybridisation. Eur J Hum Genet 2005, 13:1019-1024

33. Luciani JJ, De Mas P, Depetris D, Mignon-Ravix C, Bottani A, Prieur M, Jonveaux P, Philippe A, Bourrouillou G, De Martinville B, Delobel B, Vallee L, Croquette MF, Mattei MG: Telomeric 22q13 deletions resulting from rings, simple deletions, and translocations: cytogenetic, molecular, and clinical analyses of 32 new observations. J Med Genet 2003, 40:690-696.

34. Manning MA, Cassidy SB, Clericuzio C, Cherry AM, Schwartz S, Hudgins L, Enns GM, Hoyme HE: Terminal 22q deletion syndrome: a newly recognized cause of speech and language disability in the autism spectrum. Pediatrics 2004, 114:451-457.

35. Nesslinger NJ, Gorski JL, Kurczynski TW, Shapira SK, Siegel-Bartelt J, Dumanski JP, Cullen RF, French BN, McDermid HE: Clinical, cytogenetic, and molecular characterization of seven patients with deletions of chromosome 22q13.3. Am J Hum Genet 1994, 54:464-472.

36. Philippe A, Boddaert N, Vaivre-Douret L, Robel L, Danon-Boileau L, Malan V, de Blois MC, Heron D, Colleaux L, Golse B, Zilbovicius M, Munnich A: Neurobehavioral profile and brain imaging study of the 22q13.3 deletion syndrome in childhood. Pediatrics 2008, 122:e376-e382.

37. Soorya L, Kolevzon A, Zweifach J, Lim T, Dobry Y, Schwartz L, Frank Y, Wang AT, Cai G, Parkhomenko E, Halpern D, Grodberg D, Angarita B, Willner JP, Yang A, Canitano R, Chaplin W, Betancur C, Buxbaum JD: Prospective investigation of autism and genotype-phenotype correlations in 22q13 deletion syndrome and SHANK3 deficiency. Mol Autism 2013, 4:18.

38. Rollins JD: Growth in Phelan-McDermid syndrome. Am J Hum Genet 2011, 155:2324-2326.

39. Sarasua SM, Boccuto L, Sharp JL, Dwivedi A, Chen CF, Rollins JD, Rogers RC, Phelan K, DuPont BR: Clinical and genomic evaluation of 201 patients with Phelan-McDermid syndrome. Hum Genet 2014, 133:847-859.

40. Sarasua SM, Dwivedi A, Boccuto L, Chen CF, Sharp JL, Rollins JD, Collins JS, Rogers RC, Phelan K, DuPont BR: 22q13.2q13.32 genomic regions associated with severity of speech delay, developmental delay, and physical features in Phelan-McDermid syndrome. Genet Med 2013, 16:318-328.

41. Cusmano-Ozog K, Manning MA, Hoyme HE: 22q13.3 deletion syndrome: a recognizable malformation syndrome associated with marked speech and language delay. Am J Med Genet C: Semin Med Genet 2007, 145C:393-398.

42. Verhoeven WM, Egger JI, Willemsen MH, De Leijer GJ, Kleefstra T: PhelanMcDermid syndrome in two adult brothers: atypical bipolar disorder as its psychopathological phenotype? Neuropsychiatr Dis Treat 2012, 8:175-179.

43. Vucurovic K, Landais E, Delahaigue C, Eutrope J, Schneider A, Leroy C, Kabbaj H, Motte J, Gaillard D, Rolland AC, Doco-Fenzy M: Bipolar affective disorder and early dementia onset in a male patient with SHANK3 deletion. Eur J Med Genet 2012, 55:625-629.

44. Sarasua SM, Dwivedi A, Boccuto L, Rollins JD, Chen CF, Rogers RC, Phelan K, DuPont BR, Collins JS: Association between deletion size and important phenotypes expands the genomic region of interest in PhelanMcDermid syndrome (22q13 deletion syndrome). J Med Genet 2011, 48:761-766.

45. Wilson HL, Wong AC, Shaw SR, Tse WY, Stapleton GA, Phelan MC, Hu S, Marshall J, McDermid HE: Molecular characterisation of the 22q13 deletion syndrome supports the role of haploinsufficiency of SHANK3/PROSAP2 in the major neurological symptoms. J Med Genet 2003, 40:575-584.

46. Alpern GBT, Shearer M: Developmental Profile II. Los Angeles: Western Psychological Services; 1986.

47. Lindquist SG, Kirchhoff M, Lundsteen C, Pedersen W, Erichsen G, Kristensen K, Lillquist K, Smedegaard HH, Skov L, Tommerup N, Brøndum-Nielsen K: Further delineation of the 22q13 deletion syndrome. Clin Dysmorphol 2005, 14:55-60.

48. Slavotinek A, Maher E, Gregory P, Rowlandson P, Huson SM: The phenotypic effects of chromosome rearrangement involving bands 7q21.3 and 22q13.3. J Med Genet 1997, 34:857-861.

49. Tagaya M, Mizuno S, Hayakawa M, Yokotsuka T, Shimizu S, Fujimaki H: Recombination of a maternal pericentric inversion results in 22q13 deletion syndrome. Clin Dysmorphol 2008, 17:19-21. 
50. Watt JL, Olson IA, Johnston AW, Ross HS, Couzin DA, Stephen GS: A familial pericentric inversion of chromosome 22 with a recombinant subject illustrating a 'pure' partial monosomy syndrome. J Med Genet 1985, 22:283-287.

51. Tabolacci E, Zollino M, Lecce R, Sangiorgi E, Gurrieri F, Leuzzi V, Opitz JM, Neri G: Two brothers with 22q13 deletion syndrome and features suggestive of the Clark-Baraitser syndrome. Clin Dysmorphol 2005, 14:127-132.

52. Aldinger KA, Kogan J, Kimonis V, Fernandez B, Horn D, Klopocki E, Chung B, Toutain A, Weksberg R, Millen KJ, Barkovich AJ, Dobyns WB: Cerebellar and posterior fossa malformations in patients with autism-associated chromosome 22q13 terminal deletion. Am J Med Genet A 2013, 161A:131-136.

53. Tsilchorozidou T, Menko FH, Lalloo F, Kidd A, De Silva R, Thomas H, Smith P, Malcolmson A, Dore J, Madan K, Brown A, Yovos JG, Tsaligopoulos M, Vogiatzis N, Baser ME, Wallace AJ, Evans DG: Constitutional rearrangements of chromosome 22 as a cause of neurofibromatosis 2 . J Med Genet 2004, 41:529-534.

54. Zirn B, Arning L, Bartels I, Shoukier M, Hoffjan S, Neubauer B, Hahn A: Ring chromosome 22 and neurofibromatosis type II: proof of two-hit model for the loss of the NF2 gene in the development of meningioma. Clin Genet 2012, 81:82-87.

55. Trabacca A, Losito L, De Rinaldis M, Gennaro L: Congenital hypotonia in a child with a de novo 22q13 monosomy and 2pter duplication: a clinical and molecular genetic study. J Child Neurol 2011, 26:235-238.

56. Barakat AJ, Pearl PL, Acosta MT, Runkle BP: 22q13 deletion syndrome with central diabetes insipidus: a previously unreported association. Clin Dysmorphol 2004, 13:191-194.

57. Kirkpatrick BE, El-Khechen D: A unique presentation of $22 q 13$ deletion syndrome: multicystic kidney, orofacial clefting, and Wilms' tumor. Clin Dysmorphol 2011, 20:53-54.

58. Bartsch O, Schneider E, Damatova N, Weis R, Tufano M, lorio R, Ahmed A, Beyer $V$, Zechner $U$, Haaf $T$ : Fulminant hepatic failure requiring liver transplantation in 22q13.3 deletion syndrome. Am J Med Genet A 2010, 152A:2099-2102.

59. Tufano M, Della Corte C, Cirillo F, Spagnuolo MI, Candusso M, Melis D, Torre $\mathrm{G}$, lorio R: Fulminant autoimmune hepatitis in a girl with $22 \mathrm{q} 13$ deletion syndrome: a previously unreported association. Eur J Pediatr 2009, 168:225-227.

60. Redecker P, Bockmann J, Böckers TM: Expression of postsynaptic density proteins of the ProSAP/Shank family in the thymus. Histochem Cell Biol 2006, 126:679-685.

61. Chen CP, Lin SP, Chern SR, Tsai FJ, Wu PC, Lee CC, Chen YT, Chen WL, Wang $\mathrm{W}$ : A de novo $7.9 \mathrm{Mb}$ deletion in 22 q13.2 $\rightarrow$ qter in a boy with autistic features, epilepsy, developmental delay, atopic dermatitis and abnormal immunological findings. Eur J Med Genet 2010, 53:329-332.

62. Bonaglia MC, Giorda R, Beri S, De Agostini C, Novara F, Fichera M, Grillo L, Galesi O, Vetro A, Ciccone R, Bonati MT, Giglio S, Guerrini R, Osimani S, Marelli S, Zucca C, Grasso R, Borgatti R, Mani E, Motta C, Molteni M, Romano C, Greco D, Reitano S, Baroncini A, Lapi E, Cecconi A, Arrigo G, Patricelli MG, Pantaleoni $C$, et al: Molecular mechanisms generating and stabilizing terminal 22q13 deletions in 44 subjects with Phelan/McDermid syndrome. PLoS Genet 2011, 7:e1002173.

63. Bonaglia MC, Giorda R, Borgatti R, Felisari G, Gagliardi C, Selicorni A, Zuffardi $\mathrm{O}$ : Disruption of the ProSAP2 gene in a $\mathrm{t}(12 ; 22)(q 24.1 ; \mathrm{q} 13.3)$ is associated with the 22q13.3 deletion syndrome. Am J Hum Genet 2001, 69:261-268.

64. Boccuto L, Lauri M, Sarasua SM, Skinner CD, Buccella D, Dwivedi A, Orteschi D, Collins JS, Zollino M, Visconti P, DuPont B, Tiziano D, Schroer RJ, Neri G, Stevenson RE, Gurrieri F, Schwartz CE: Prevalence of SHANK3 variants in patients with different subtypes of autism spectrum disorders. Eur J Hum Genet 2013, 21:310-316.
65. Hamdan FF, Gauthier J, Araki Y, Lin DT, Yoshizawa Y, Higashi K, Park AR, Spiegelman D, Dobrzeniecka S, Piton A, Tomitori H, Daoud H, Massicotte C, Henrion E, Diallo O, S2D Group, Shekarabi M, Marineau C, Shevell M, Maranda B, Mitchell G, Nadeau A, D'Anjou G, Vanasse M, Srour M, Lafrenière RG, Drapeau P, Lacaille JC, Kim E, Lee JR, et al: Excess of de novo deleterious mutations in genes associated with glutamatergic systems in nonsyndromic intellectual disability. Am J Hum Genet 2011, 88:306-316.

66. Betancur C, Buxbaum JD: SHANK3 haploinsufficiency: a "common" but underdiagnosed highly penetrant monogenic cause of autism spectrum disorders. Mol Autism 2013, 4:17.

doi:10.1186/1866-1955-6-39

Cite this article as: Kolevzon et al:: Phelan-McDermid syndrome: a review of the literature and practice parameters for medical assessment and monitoring. Journal of Neurodevelopmental Disorders 2014 6:39.

\section{Submit your next manuscript to BioMed Central and take full advantage of:}

- Convenient online submission

- Thorough peer review

- No space constraints or color figure charges

- Immediate publication on acceptance

- Inclusion in PubMed, CAS, Scopus and Google Scholar

- Research which is freely available for redistribution

Submit your manuscript at www.biomedcentral.com/submit
C) BioMed Central 